\title{
潰瘍性大腸炎の再燃に伴い一過性全健忘の 再発作をきたした症例
}

A Case of Recurrent Transient Global Amnesia with Recurrent Ulcerative Colitis

\section{渡 邊 秀 寿 川村正太郎}

Hidetoshi Watanabe, Shotaro Kawamura

\begin{abstract}
要 旨
潰瘍性大腸炎の初回診断時に一過性全健忘を呈した症例が, 潰瘍性大腸炎の再燃時に一過性全健忘の再発作を きたした，精神的ストレス，疼痛等が一過性全健忘の誘因となると報告されているが，潰瘍性大腸炎の再燃も 誘因となる可能性が示唆された。プライマリケア医を含め, 潰痬性大腸炎の治療に携わる医師は一過性全健忘 の合併につき知っておく必要がある.
\end{abstract}

Keywords：潰瘍性大腸炎（Ulcerative colitis），一過性全健忘（Transient global amnesia）

\section{はじめに}

一過性全健忘 (Transient global amnesia, 以下 TGA と略す）は，一時的な記銘力障害と逆行性健忘をきた す発作である，その原因は明らかではないが，精神的 ストレス, 疼痛等が誘因として報告されている ${ }^{1}$. 今回, 潰瘍性大腸炎の初回診断時に TGA を呈した患者が, 潰瘍性大腸炎の再燃とともに TGA の再発作をきたし た症例を経験した. TGA の原因に関して示唆を与える 症例と思われるため報告する。

\section{症 例}

\section{[初回発作時]}

患者は 66 歳男性. 15 年前に胃癌の手術歷があり, 高 血圧に対して近医よりテルミサルタン・アムロジピン ベシル酸塩を処方されていた. 瓶ビール1本/日を週 7 日の飲酒歴があり， 1 年前に禁煙したものの 40 本/日 45 年間の喫煙歴があった.

3 週間前から持続する血便, 間欠的腹痛を主訴に当 院消化器内科を初回受診した. 初診より 2 日後に下部 消化管内視鏡を施行され，大腸粘膜に多発性の糜爛， 潰瘍が見られ入院となった．生検では大腸粘膜の再生 変化とともに粘膜全層の炎症細胞浸潤, 杯細胞の減少
を認め潰瘍性大腸炎と診断された。内視鏡検査は $2 \%$ キシロカインゼリーを使用するのみで鎮静薬を使用せ ずに施行できた，検查後「ここはどこですか？」「なん でここにいるのですか？」等の質問を繰り返した，見 当識障害以外に失語, 失行等の神経学的異常を認めず, 翌日には速やかに見当識障害は改善した，見当識障害 発症から約 48 時間後に撮影した頭部 MRI では明らか な異常を認めなかった. Hodgesらが提唱した診断基 準, Caplan の診断基準（表 1）を満たし TGA と診断 された。

潰瘍性大腸炎に対してはメサラジン $4 \mathrm{~g} /$ 日, プレド ニゾロン $40 \mathrm{mg} /$ 日を投与され入院 27 日目に退院と なった，外来でプレドニゾロンの漸減を行い，メサラ ジンのみで維持療法を継続した。

\section{[2 回目発作時]}

初回の発作より約 3 年後, 患者 69 歳時, 同じことを 何回も尋ねる事を主訴に，妻に連れられ当院救急外来 を受診した．朝食後何回も「朝ごはん食べたか？」と 聞くようになり，その後自分で自動車を運転し絵画展 に行ったものの「ここはどこ？」「これは誰の絵かな？」 等の質問を繰り返した，来院時，見当識障害を認めた ものの, 麻疩, 失語, 失行等の神経学的異常はなかっ

一宮西病院救急科

著者連絡先：渡邊秀寿 一宮西病院救急科 [T 494-0001 愛知県一宮市開明字平 1 番地］ email: oto.nabe@gmail.com

（受付日：2016 年 6 月 16 日, 採用日：2016 年 10 月 10 日）

(C)2017 日本プライマリ・ケア連合学会 


\section{表 1 TGA の診断基準}

$<$ Hodge らの診断基準 $>$

1. 発作が目撃され, その内容について十分な情報が観 察者から得られる.

2. 発作中に明瞭な前向性健忘が見られる。

3. 意識の混濁や自己の見当識障害はなく, 認知の障害 は健忘に限られる.（失語・失行などの症状がない）

4. 発作中, 神経学的局所徵候は合併せず, 発作後も重 大な神経学的異常を認めない.

5. 癲痌の徴候を欠く.

6. 発作は 24 時間以内に消失する.

7. 発作を生じたころに頭部外傷を受けた患者および

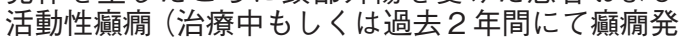
作を認めたもの) の患者は除外する.

$<$ Caplan の診断基準 $>$

1. 発作が目撃されて, 発作時の情報が得られる.

2. 発作中の患者は同じ質問を繰り返すが, 不自然な振 る舞いはない.

3. 他の神経徴候がない.

4. 記憶障害は一過性である.

た. 発症から 12 時間以内に撮影された頭部 MRI では 異常を認めず, TGA を疑われ神経内科に入院となっ た. 来院時は潰瘍性大腸炎を疑わせる症状はなかった ものの, 入院時の採血で白血球の上昇を認めたため腹 部 CT を撮影したところ, S 状結腸から直腸の粘膜下 腫脹を認め潰痬性大腸炎の再燃が疑われた。

入院翌日には見当識障害も改善し TGA の再発作と 診断されたが, 同日より発熱, 腹痛, 血便を認めた. 下部消化管内視鏡では大腸粘膜の発赤 ·糜爛 - 易出血 性を認め, 潰瘍性大腸炎の再燃と判断された. 消化器 内科に転科となり, プレドニゾロン投与が再開された. 患者の早期退院希望もあり8病日で自宅退院となっ た。

退院後の 13 病日に脳波検査を行うも, 明らかな異常 を認めなかった。

2 回目の TGA 発作後も外来経過観察中であるが, 潰 瘍性大腸炎再燃, TGA 発作とも認めていない.

\section{考 察}

潰瘍性大腸炎の日本国内の患者数は平成 25 年度の 医療受給者証および登録者証交付件数の合計からみる と約 16 万人である. 潰瘍性大腸炎は根治的な治療法が なく, 再燃と緩解を繰り返し長期間の治療を要する。 消化器科専門医のみならずプライマリケア医も治療に
携わることが多い疾患である.

TGA は年間の発症率は人口 10 万人当たり 5.2 人 と言われ，24 時間以内に症状が消失する疾患である. 傷病経過が短くプライマリケア医が目にする機会は多 くない.

TGA の病態機序については, 脳虚血説, 癲痱説, 片 頭痛説等が挙げられているが, いまだ統一された見解 は得られていない. 今回の症例では頭痛の訴え, 癲痌 の既往ともになく, 脳波検査でも異常はなかった. TGA の病態として海馬周辺の血流障害が推定されて いるが ${ }^{3)}$ MRI 画像では異常所見は得られなかった.

TGAの誘因として精神ストレス, 性行為, 疼痛, 冷 水浴 ${ }^{1)}$ 等が報告されている.

TGAの再発例は追跡期間によっても異なるが約 $10 \%$ から $25 \%$ と報告されている ${ }^{4)}$. 消化管内視鏡が TGA の誘因となったとする報告 ${ }^{5)}$ は存在するが, 今回 の症例では 2 回目の TGA 発作は消化管内視鏡を施行 する前に発症しており, 潰瘍性大腸炎の病勢そのもの がTGAの誘因となった可能性がある.

プライマリケア医を含め潰瘍性大腸炎の治療に携わ る者は, TGAの合併につき留意する必要がある. 今回 の症例のように潰瘍性大腸炎の再燃と合わせて再発し た症例の報告はなく，更に報告を集積することが望ま れる。

\section{文 献}

1) Fisher CM. Transient global amnesia. Precipitating activities and other observations. Arch Neurol. 1982; 39(10): 605-608.

2) Miller JW, Petersen RC, Metter EJ, et al. Transient global amnesia: clinical characteristics and prognosis. Neurology. 1987; 37(5): 733-737.

3) Bartsch T, Alfke K, Stingele R, et al. Selective affection of hippocampal CA-1 neurons in patients with transient global amnesia without long-term sequelae. Brain. 2006; 129: 2874-2884. doi: 10.1093/brain/awl248

4) Quinette P, Guillery-Girard B, Dayan J, et al. What does transient global amnesia really mean? Review of the literature and thorough study of 142 cases. Brain. 2006; 129: 1640-1658. doi: 10.1093/brain/aw1105

5）塚田健一郎, 宮林千春, 古川浩一, 他. 上部消化管内視鏡 検査後に, 一過性全健忘をきたした 3 症例. 日本消化器内 視鏡学会雑誌. $2006 ； 48 （ 6 ） ： 1215-1220$. 